\title{
DESCRIPTIONS OF THREE SPECIES OF SAND FLEAS (AMPHIPODS) COLLECTED AT NEWPORT, RHODE ISLAND.
}

\author{
By Sylvester D. Judd.
}

While at Mr. Agassiz's Newport laboratory in the summer of 1893, I collected a large number of crustaceans. Of these, the Amphipods particularly interested me. They were obtained by skimming the ealm surface of Narragansett Bay at night with a "tow net."

Most of the Amphipods found in the skimmings or "tow" belonged to the family Gammaridæ, a typical representative of which is Gammarus, our common Sand Flea.

\section{CALLIOPIUS RATHKEI (Zaddach).}

Some little olive-colored Gammarids, which might at first be taken for Gammarus, proved to be very interesting. Unlike Gammarus, they did not rise to the surface of the water with a succession of springs, but moved rapidly through the water at a uniform rate. They often bumped against the side of the dish, but never stopped the incessant vibration of their legs until a secure hiding place had been reached.

Female.-A large white shield on the back formed a conspicuous and distinctive feature by which they were easily recognized. These Amphipods agree with the description of Calliopius rathkei given by Sars ${ }^{2}$ more closely than with the description of any other known species. However, they constantly differ slightly from the European form ${ }^{3}$ of that species in certain details, as for instance antennal sense organs, color, etc., which are sufficiently constant to warrant their description.

The points of difference may be considered in the following order: Color, size, coxæ, and calceoli.

\footnotetext{
${ }^{1}$ For the invaluable aid received in the preparation of this paper, I have to thank Dr. W. Faxon and Prof. E. L. Mark, of Harvard University.

${ }^{2}$ Crustacea of Norway, 1893, I, Pt. 20.

${ }^{3}$ For the sake of convenience, I shall allude to the animals hitherto described, as the European form-to those which I have studied, as the American form-of Calliopius rathkiei.
}

Note.-Abbreviations: ant. anterior; d.dorsal; dist. distal; l. lateral; m. median; pot. posterior; $p x$. proximal; v. ventral.

Proceedings of the United States National Museum, VOL. XVIII-No. 1084.

Proc. N. M. $95-38$. 
Sars, ${ }^{1}$ in his description of the female, says: "Body semipellucid, with a yellowish violet tinge, and mottled with irregular specks of a cleas orange hue, each segment being, moreover, bordered posteriorly by a narrow band of dark, reddish brown pigment; on the anterior part of the back occurs, besides, a rather conspicuous rounded shield of a silvery luster, occupying the dorsal face of the third and fourth segments of mesosome." The Newport specimens possess a silvery shield, like the European form, but the rest of the body is dark olive, thus making the animal opaque rather than semipellucid. From the tip of the rostral projection of the cephalon to the tip of the telson the American form measures $6.5 \mathrm{~mm}$., the European only 6 . The coxa of the last segment of the pereion (Fig. 1) is as long in the longitudinal as in

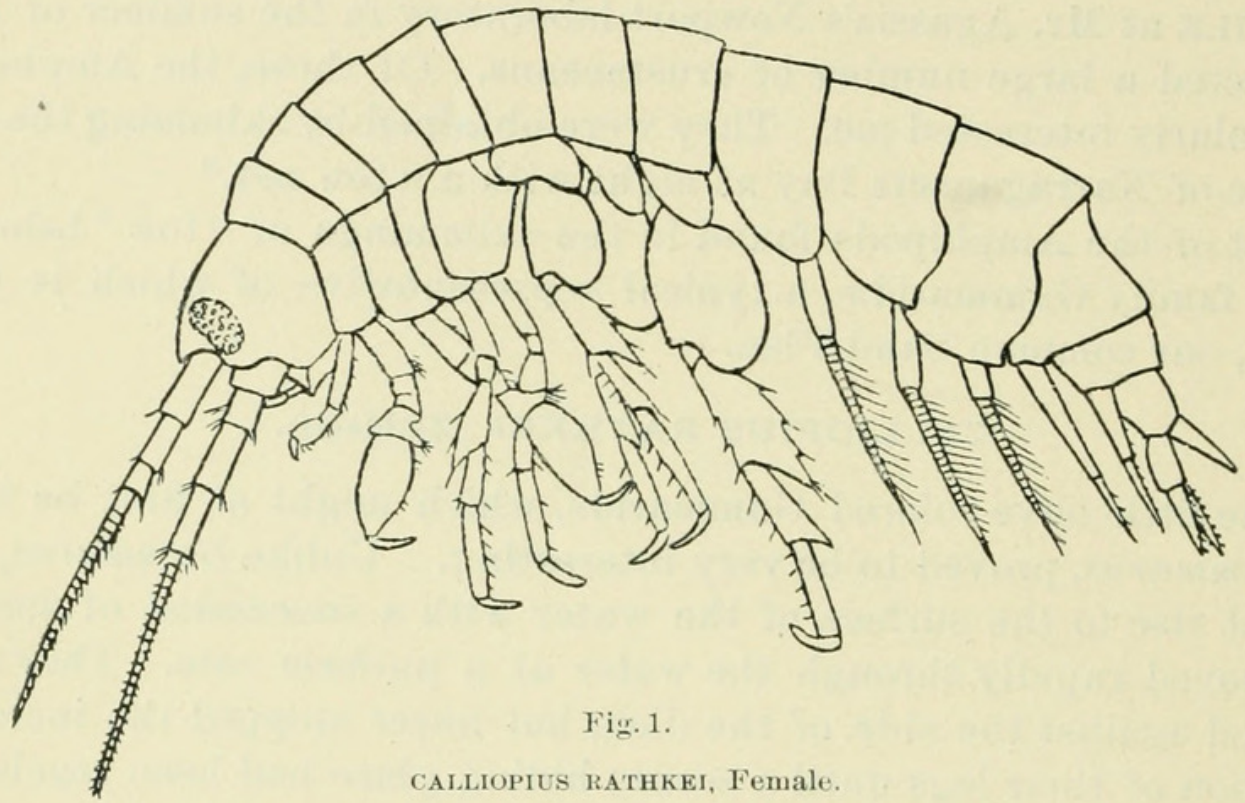

the dorso-ventral direction. In the specimen figured by Sars ${ }^{2}$ the dorso-ventral measurement is not much more than half as great as the longitudinal.

Sars, in his work on the European form, figures ealceoli, ${ }^{3}$ but says nothing of their structure. In the American form, calceoli occur on both pairs of antennæ. Each calceolus consists of two parts. The basal or proximal part has the form of a wineglass. On this rests the distal part, which has the form of a slipper, the attachment being by means of the end corresponding to the heel of the slipper. While in Sars' specimens the heel and toe parts are in the same plane, in my specimens they are bent so as to make an angle of about $160^{\circ}$ with each other.

The position of the calceoli is important. Each articulus of the flagellum of the superior antenna bears two calceoli, which are situated on the ventral portion of the articulus near the distal margin. Both may be seen in the view of the antenna from its median side (Fig. $2 a$ ). 
Small bristling hairs encircle the bases of both calceoli. The more ventral of the two calceoli is nearer the distal margin of the articulus and close to two long blunt cylindrical hairs. (Fig. $2 b, 2 c$.)

These hairs obscure the ventral calceolus in a view from the lateral side, for they are just outside or lateral to the calceolus. In the enlarged view given by Sars ${ }^{1}$

these ventral calceoli are seen with distinctness; just dorsal to a number of these rentral calceoli is a series of circles. If these circles are meant for calceoli, I think that Sars is in error, because the median cal-

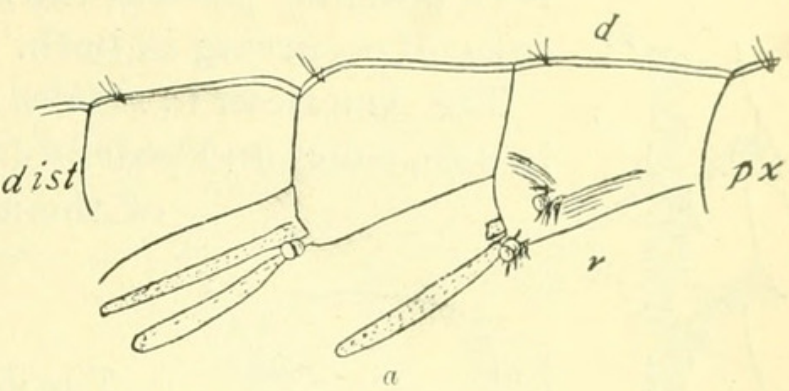
ceoli lie on the opposite (median) face and could not be seen in this view of the appendage.

Sars states with emphasis that the terminal lappet of the third articulus of the flagellum has only two calceoli. The American representative has four at least.

Each articulus of the flagellum of the inferior an. temna bears two calceoli on its median face (Fig.3). One calreolus is more dorsal than the other. The dorsal calceolus springs from a point at some listance proximal to that from which the ventral calceolus arises. A lateral view of the appendage shows the calceoli ouly dimly, if at all, for the antenna is too opaque to allow them to be seen with distinctne'ss through it. In a similar

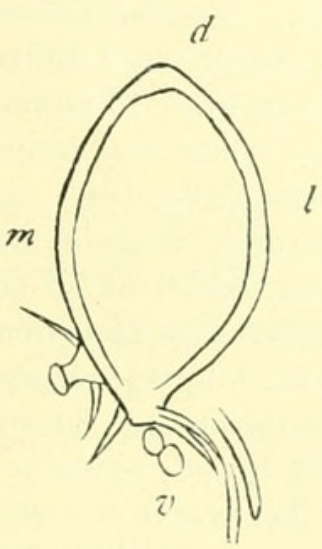

\section{l}

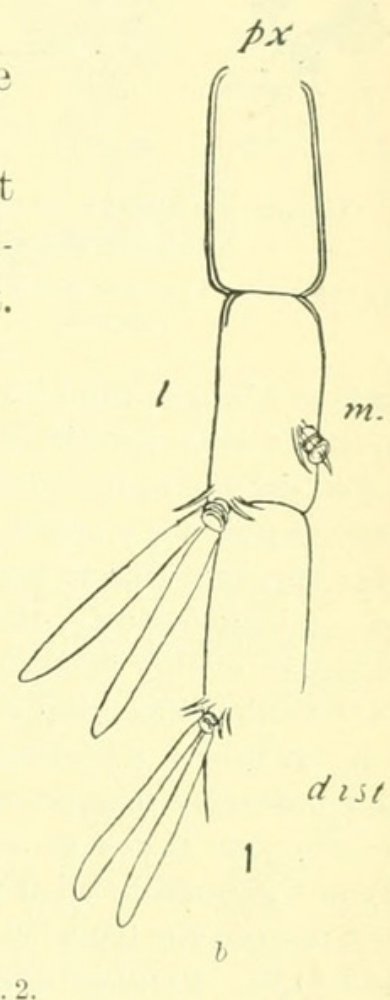

Fig. 2.

SUPEIIOR ANTENAa OF CALLIOPIUS RATHKEI, Female.

I dian surface with calceoli; (b) ventral surface of fifth to seventh segments; (c) cross section.

view, Sars shows distinctly the ventral calceoli, and leaves us to interpret a series of circles which lie dorsal to them.

While there are two rows of calceoli on each of the antennæ of my specimens of Calliopius rathkei, in Sars' description of the genus Calliopius $^{2}$ I find no allusion to more than a single row of these organs; lut, in view of the fact that C. laviusculus and the American form of C. rathkei both possess two rows of calceoli on each of the four antennæ, I am led to believe that the European form of $C$. rathkiei probably also

Pl. 157, fig. $2 \mathrm{c}$.

2 Specimens of $C$. laviusculus, which were procured from the Museum of Comparative Zoology in Cambridge, Massachusetts, through the kindness of Dr. Walter Faxon, sbowed two rows of calceoli ou each antenna. 
possesses two rows, one of which has been overlooked by all previous writers. ${ }^{1}$

In the American representative of $C$. rathkei, the superior antenna appears more serrated than the inferior. This is because there are no calceoli on the ventral face of the inferior antenna. In Sars' figure both antennæ possess the same degree of serration, ventral

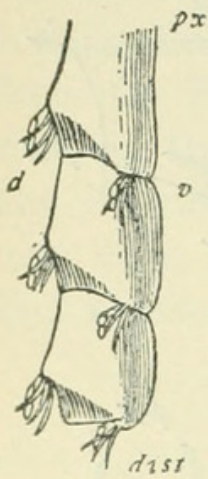

$a$

INFERIOR ANTENNA OF CALLIOPIUS RAthkei, Female.

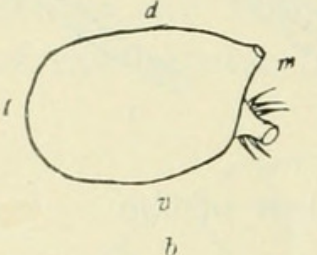

Fig. 3 calceoli occurring in both.

The American C.rathkei differs, then, from the European in size, color, and possibly in the number and arrangement of the antennal sense organs.

\section{BYBLIS SERRATA.}

The description of Byblis serrata given by Prof. S. I. Smith ${ }^{2}$ is as follows:

Female: Dorsum rounded above, with no trace of a longitudinal earina upon the abdomen; third segment of the abdomen broadly rounded at the postero-lateral angle. Antennula about as long as the peduncle of the antenna; fourth segment of the peduncle of the

antenna longer than the fifth. Inferior margins of the epimera of the first and second pairs of legs serrate, with slender and acnte teeth alternating with the marginal cilia; carpus in the first pair scarcely if any longer than the propodus; carpus in the second pair very much longer than the propodus. In the third and fourth pairs of legs the dactylus as long as the propodus. Basal segment in the seventh pair of legs expanding distally, the posterior margin nearly straight, the anterior and inferior margins evenly arenated, and reaching as far as the distal end of the carpus; the carpus about as long as the ischium and merus together, a little less than twice as long as broad, and armed with long spines upon the anterior and distal margins, but the posterior margin wholly unarmed; propodus almost as long as the carpus, and nearly four times as long as broad, anterior margin unarmed, the posterior armed upon the outside with two transverse rows of three or four spines, decreasing in size as they recede from the margin, the distal end with a spine each side the slender dactslus. Rami of the first pair of caudal stylets equal, as long as the base; outer rami of the second pair shorter than the inner; rami of the posterior pair equal, longer than the bases, reaching to the tips of the rami of the first pair. Telson as long as breadth at base, eleft rather more than half its length, the lateral margin areuate and rapidly converging toward the evenly rounded extremity.

Alcoholic specimens are pale yellowish; the epimera, bases of posterior legs, and the sides of the abdomen specked and mottled with numerous points of dark pigment crowded irregularly together.

Length, 10-12 mm. Deep water off Vineyard Sound and Buzzards Bay.

To this accurate description of Professor Smith's I should like to add a general view (Fig. 4), and a few remarks about the living animal.

My specimens were skimmed from the surface at night. They were

Through the kindness of Professor Sars, I have been able since writing this paper to examine several specimens of the European form of C. rathkei collected by him. These specimens were smaller than mine, but, like them, possessed two rows of calceoli on each of the four antennie.

${ }^{2}$ Rept. U. S. Fish Com., 1871-72, p. 561. 
more sluggish than Gammarus, being wont to lie curled up on the surface of the water. In color they were translucent pearly white; around the bases of the legs of the pereion were fantastically branched stellate

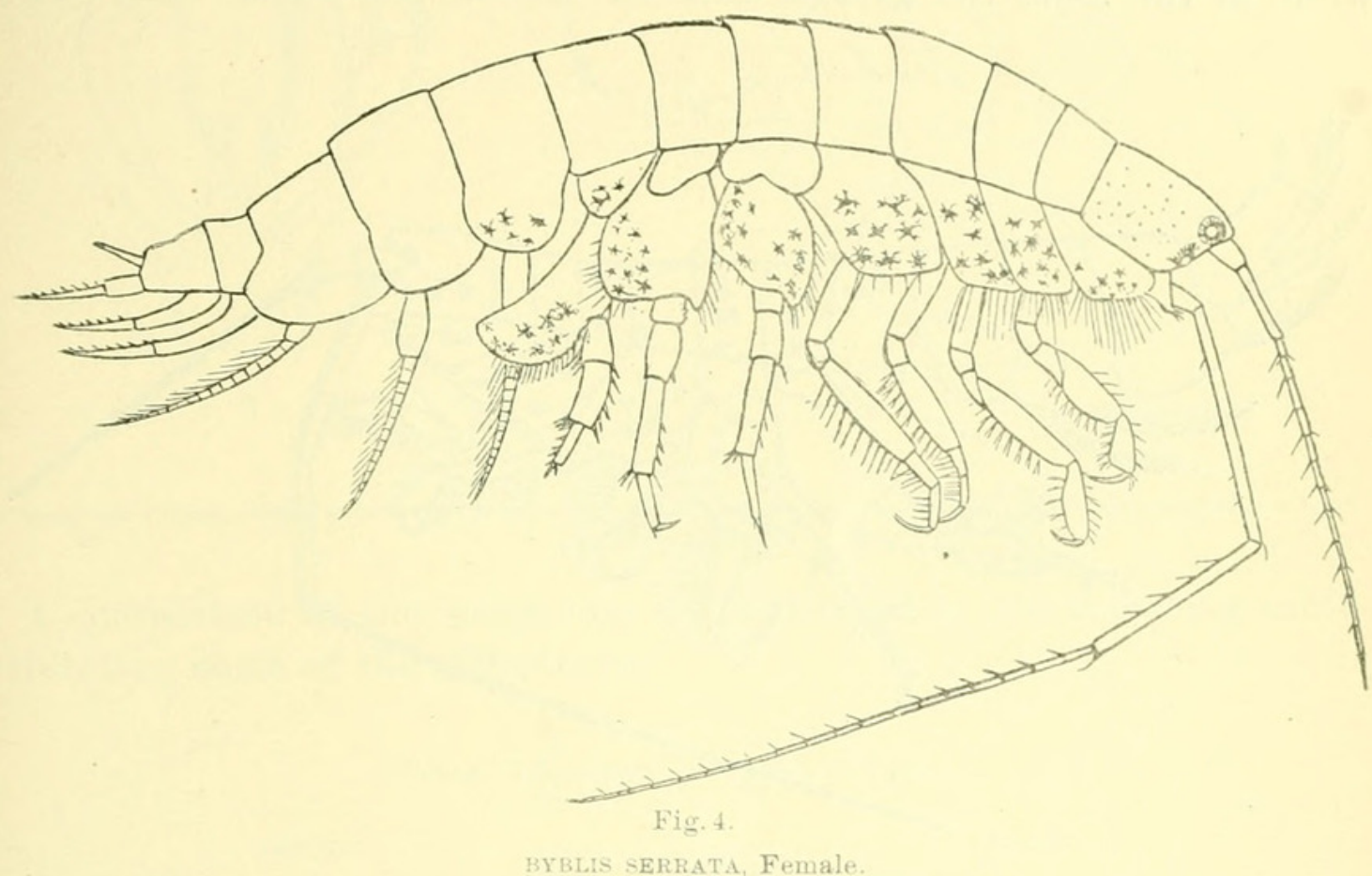

pigment cells of a rich purplish brown color. The mass of eggs in the brood pouch appeared like a claret-red globe. The four eyes were usually bright red, with considerable pigment around their sloping sides.

In a few individuals the eyes were black, and in alcoholic specimens the red eyes turn black.

Male.-In looking over several hundred specimens of Byblis serrata, now and then I came across one that had died in a straight condition, instead of being more or less curled up like the others. The straight ones possessed no incubatory pouch, were smaller, and had

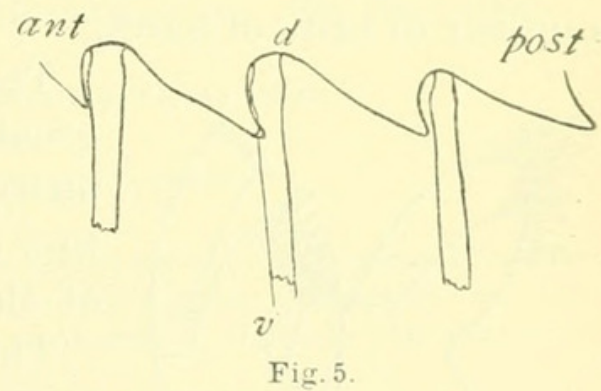

BYblis serrata, Female. First coxa showing serration of ventral margin. very long inferior antennæ; they were apparently the males of Byblis serrata, for they had serrated coxæ (Fig. 5). ${ }^{1}$ The differences are those usually characteristic of the sexes in this genus. ${ }^{2}$

The antennæ especially are the organs which exhibit sexual dimorphism in the family Ampeliscidie.

${ }^{1}$ For resemblances and differences compare figs. 4 and 6 .

${ }^{2}$ See the table of sexual differences in Byblis gaimardi, a typical species of the genus, p. 601 . 
The hairs on the peduncle of the superior antenna are arranged in bristle-like tufts in the male only. There is a collection of long hairs near the base of the flagellum in the male, but none in the female.

In the female the greater part of the hairs occur on the ventral side, while in the male the greater number are on the dorsal side. The

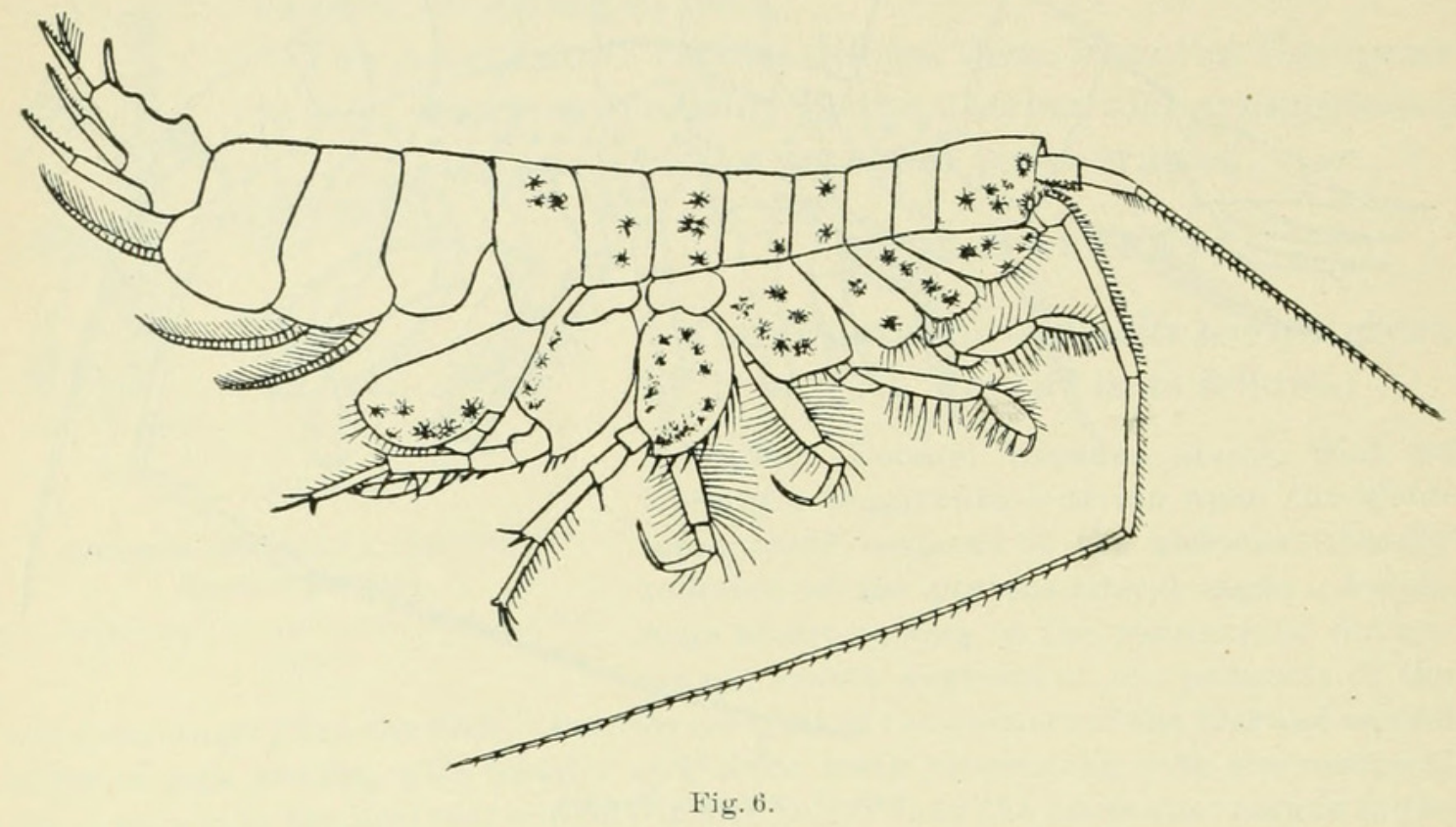

BYBLIS SERrAtA, Male.

inferior antennæ of the male, like the superior ones, possess tufts of hairs on the peduncle; in the female these are wanting. In the male the third joint of the peduncle is swollen, and thus supports a larger number of tufts of hairs.

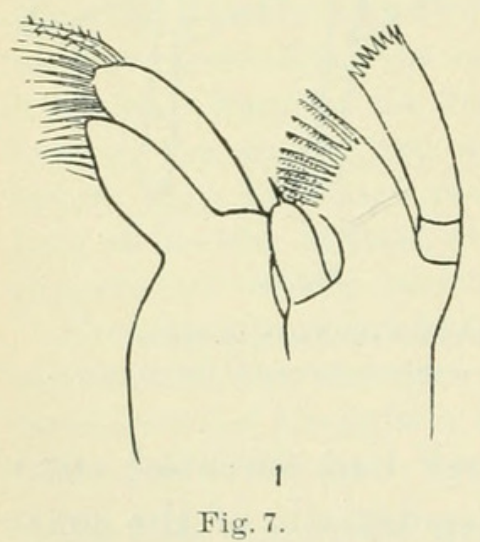

BYBLIs SERRATA, Female.

First and second maxillæ of left side, ventro-lateral surface.

The flagellum of the inferior antenna is greatly elongated in the male. This peculiarity as well as the increased number of olfactory tufts may be connected with the functions of the male in seeking the female.

The acute teeth on the ventral margin of the coxæ of the female are represented in the male by blunt cones.

In the male the last three segments of the pleon are so coustricted at the articulation with the preceding segment of the pereion as to allow great freedom of motion to the terminal part of the body, and this may be of service in copulation. In this sex, too, the inner ramus of the last appendage bears, in addition to the rows of spines found on both rami of the female, long hairs. (See Fig. $8 c$ ). These hairs probably aid in the union of the sexes. In both sexes the opposing edges of the rami are serrated; but they extend to the tip of the ramus in the male 
only. These serrated margins present a notch in the male (Fig. $8 c$ ), but there is none in the female.
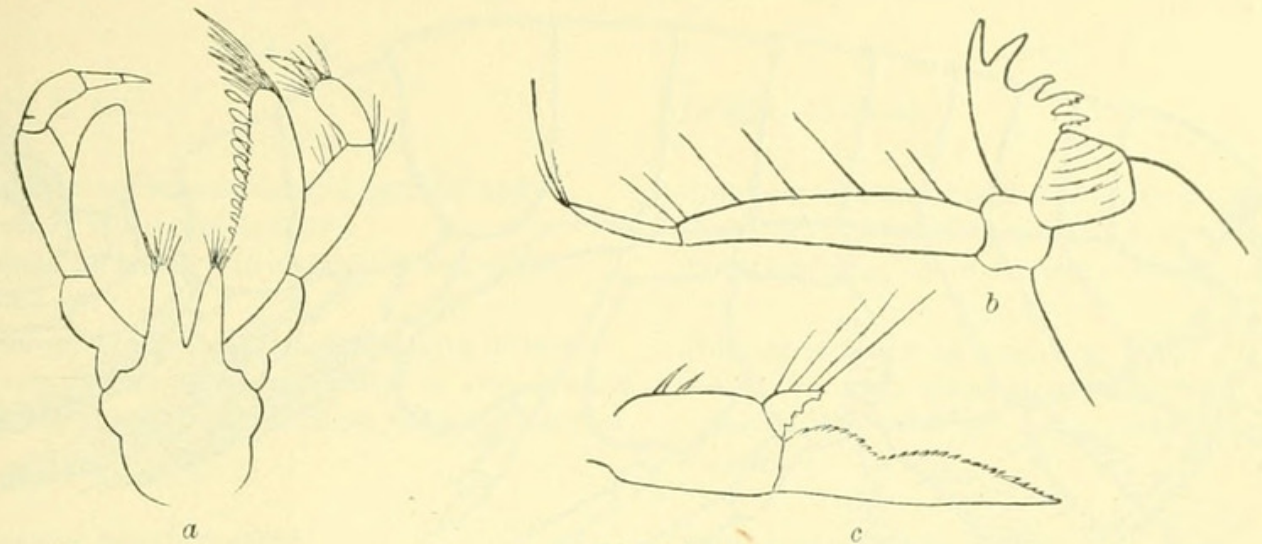

Fig. 8.

BYBLIS SERRATA.

(a) Maxilliped of female, ventral surface ; (b) left mandible of female, median surface; (c) left pleopodos of male, only basal portion of inner ramus.

A comparison of the sexes may be facilitated by the following table exhibiting some of the differences:

Sexual differences of Byblis serrata.

Length, $11 \mathrm{~mm}$.

Superior antenna one-third length of body.

Peduncle: hairs not in tufts.

No fringe of long hairs at base of flagellum.

Inferior anteuna three-fourths length of body.

Peduncle: four-fifths of hairs on ventral side; no tufts of hairs; third joint not swollen.

Coxa: serration of teeth acute.

Incubatory pouch present.

Last three segments of pleon separated from pe reion by a slight annular constriction; ultimate and antepenultimate segments without dor al elevations.

\begin{abstract}
Length, $9.5 \mathrm{~mm}$.
Superior antenne two-fifth+length of body. Peduncle: brush-like tufts of hairs.

Fringe of long hairs at base of flagellum.

Inferior antemue $1 \frac{1}{3}$ length of body.

Peduncle: four-fifths of hairs on dorsal side; brush-like tufts of hairs; third joint swollen.

Coxa: serration of teeth blunt.

Incubatory pouch absent.

Last three segments of pleon separated from pereion by a deep annular constriction; ultinate and antepenultimate segments with dorsal elevations.
\end{abstract}

Last pair of appendages very different in male and female.

BYBLIS AGASSIZI, new species.

About June 20, I obtained a dozen Amphipods that might be readily taken for the males of Byblis longicornis, for their inferior antennæe were longer than their bodies and they lacked pigment cells.

Type.-No. 18919 , U.S.N.M.

The male of B. longicornis has not, so far as I can find, been described. It might therefore appear that these specimens were the undiscovered 
males of this species; but they differ from the females of B. longicornis in points which I think are not easily explained as due to differences of sex.

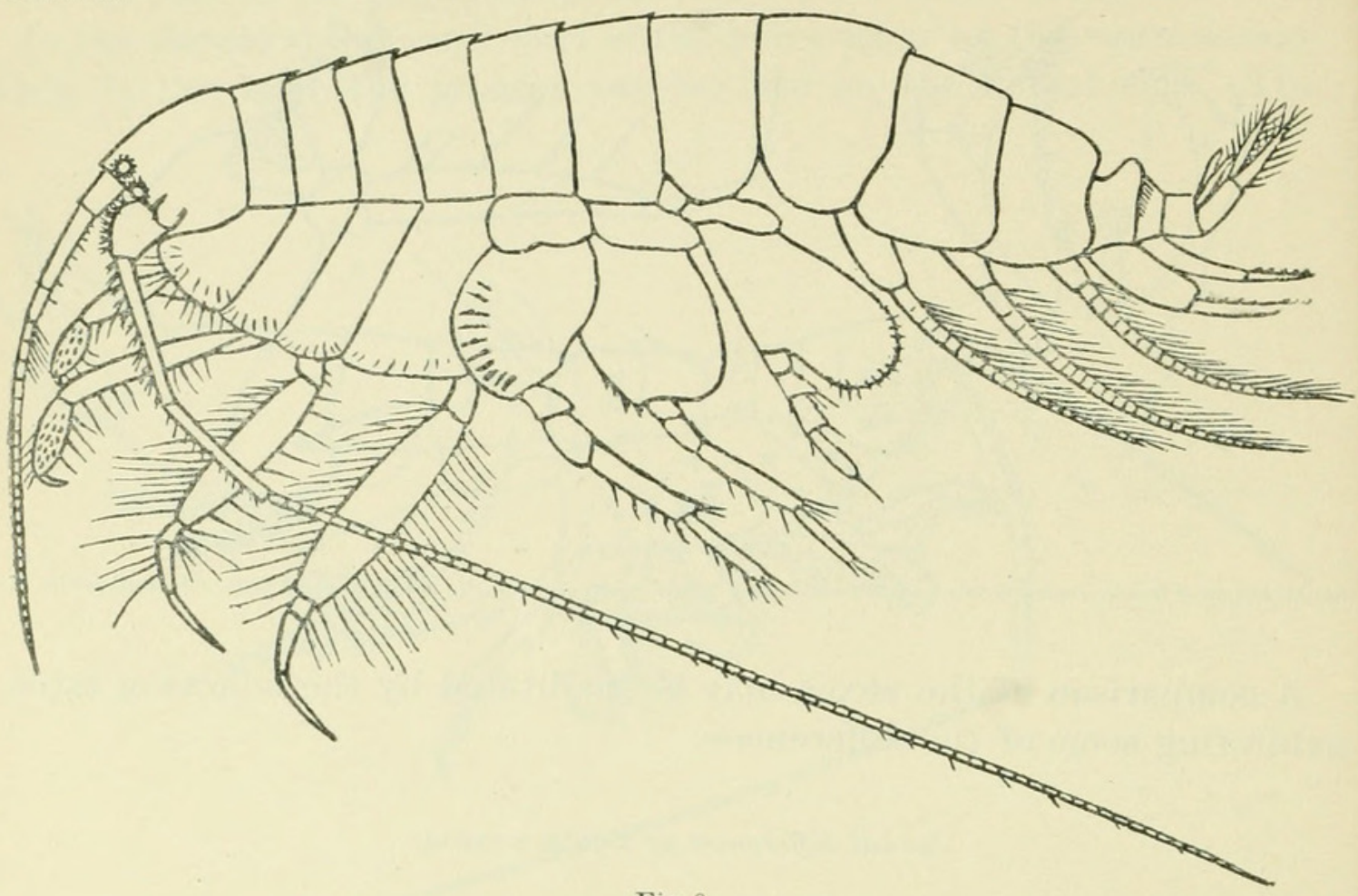

Fig. 9.

Byblis agassizi, Male.

By studying the sexual differences exhibited by the type species of the geuus, $B$. gaimardii, we shall be better prepared to state whether
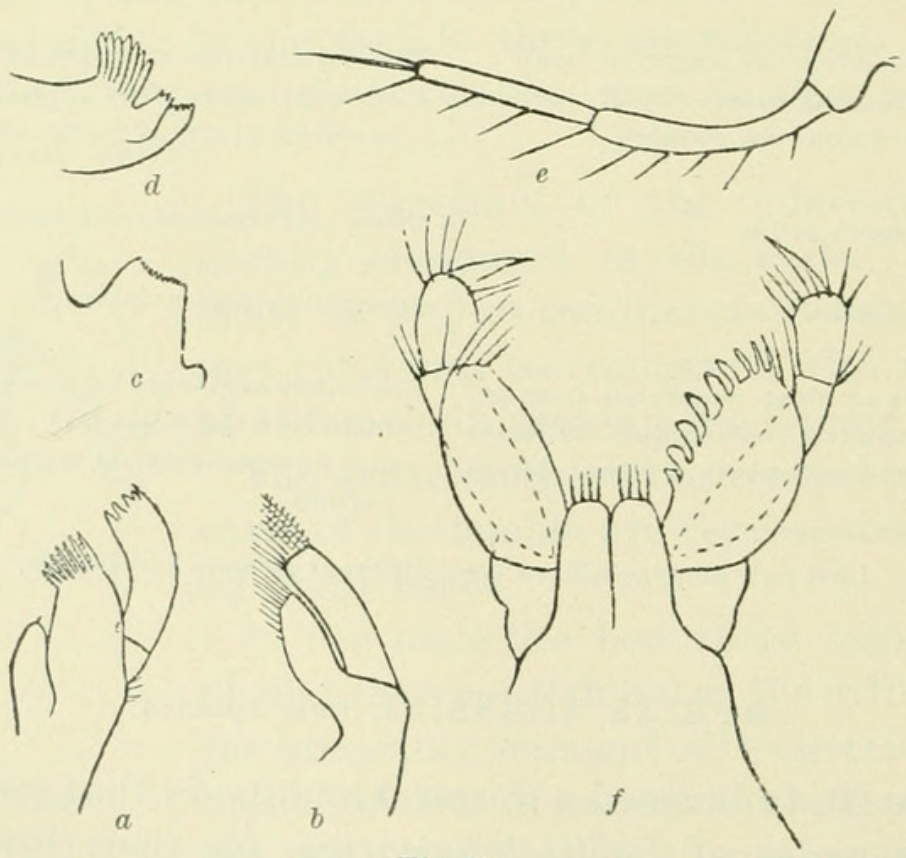

Fig. 10.

BYBlis AgAssizi, Male.

(a) First and (b) second maxilla of left side, ventro-lateral aspect; (c) grinder in profile; $(d)$ right mandible, median face of cutting edge; (e) palpus, median face; $(f)$ maxilliped, ventral view.

or not a given difference is probably to be included under the category of sexual peculiarities. 
To render the comparison easier, I have tabulated the conditions, as follows :

Sexual differences of Byblis gaimardii.

FEMALE.

Length, $15 \mathrm{~mm}$.

Superior antennæ one-third length of body. Peduncle: Hairs not in tufts.

No fringe of long hairs at base of flagellum.

Inferior antennæ three-fourths length of body.

Peduncle: Four fifths of hairs on the ventral side; no tufts of hairs; third joint not swollen.

Incubatory pouch present.

Last three segments of pleon separated from the pereion by a slight annular constriction.

Rami of last pleopodos bear no long hairs.
MALE.

Length, $13.5 \mathrm{~mm}$.

Superior anteñæ one-half length of body. Peduncle: Brush-like tufts of hairs.

Fringe of long hairs at base of flagellum.

Inferior antennæ 1 s length of body.

Peduncle: Four-fifths of hairs on the dorsal side; brush-like tufts of hairs; third joint much swollen.

Incubatory pouch absent.

Last three segments of pleon separater from the pereion by a deep annular constriction.

Inner ramus of last pleopodos has long hairs on outer edge.

Telson lowger than broad.

Telson as long as broad.

A comparison of the preceding table with that of the two sexes of Byblis serrata (p. 599) will further illustrate the nature of the characters that are subject to sexual dimorphism.

It will now be instructive to assume that the Newport specimens are males of Byblis longicornis, and to construct a provisional table exhibiting the differences between the two animals. The table is as follows:

\section{Sexual differences of Byblis longicornis.}

FEMALE.

Length, $8 \mathrm{~mm}$.

Superior antennæ two-thirds length of body. Peduncle: Hairs not in tufts.

No fringe of long hairs at base of flagellum.

Inferior antennæ $1 \frac{1}{4}$ length of body.

Peduncle: Four-fifths of hairs on rentral side; no tufts of hairs; third joint not swollen.

Nine-tenths hairs on ventral side of flagellum.

Incubatory pouch present

Last three segmen s of pleon separated from pereion by a slight annular constriction.

Rami of last pleopodos bear no long hairs.
MALE.

Length, $8.5 \mathrm{~mm}$.

Superior antennæ two-fifths length of body.

Peduncle: Hairs in brush-like tufts.

Fringe of long hairs at base of flagellum.

Inferior antennæ $1 \frac{1}{4}$ length of body.

Peduncle: Nine-tenths of hairs on dorsal side; brush-like tufts of hairs; third joint very much swollen.

Nine-tenths hairs on dorsa! side of flagellum.

Incubatory pouch absent.

Last three segments of pleon separated from pereion by a deep annular constriction.

Two rami of last pleopodos bear long hairs on both edges. 
This table is evidently inconsistent with the condition which obtains in B. gaimardii and other members of the family, for in this family the males should be smaller than the females and have longer antennæ.

The following is a table of other differences, which are sexual, if my specimens are males of B. longicornis; but if they are simply sexual differences, then this species exhibits by far the most exaggerated case of sexual dimorphism known in the family.

Bybles longicornis.

FEMALE.

Dorsum a continuous curve.

Segmentation in both pairs of antennæe equally distinet.

Ocular pigment "well defined." I

Posterior margins of first four coxie rounded.

Segments 5 and 6 of pleon have dorsal peaks.
Lyblis, new species.

MALE.

Dorsum showing toothed appearance just behind the cepha!on.

Segmentation much less distinct in inferior pair of antennæ.

Ocular pigment absent.

Posterior margins of first four coxæ not so rounded. rather truncated.

Segments 5 and 6 of pleon have no peaks.

The following is a table of differences which affect parts not usually subject to sexual dimorphism in this family:

Byblis longicornis.

FEMALE.

Length, $8 \mathrm{~mm}$.

Superior antennæ two-thirds length of body.

Diameter of dorsal lens of eyes equal to diameter of ventral lens.

Cephalon: "Lower corner well marked and sharp ;"2 much longer than broad.

Anterior periopoda : "Propodal joint little longer than carpal;" dactylus equals propodos.

No division between second and third last seg. ments of pleon.

Last pleopodos: "Opposite edges " of rami " finely serrated;" rami with no long hairs.
Byblis, new species.

MALE.

Length, $8.5 \mathrm{~mm}$.

Superior antennæ two-fitths length of body.

Diameter of dorsal lens of eyes two thirds diameter of ventral lens.

Cephalon: Lower corner not sharp; slightly longer tian broad.

Anterior periopoda: Twice as long as the carpal ; dactylus longer than propodos.

A V-shaped division area between last three segments of pleon.

Last pleopodos: Opposite edges of rami not serrated; two rami bear on both edges long hairs.

Telson cleft three-fourths its length. 
The differences in the above table are so numerous and important as to warrant the belief that these specimens are the males of a new species of Byblis, for which I would suggest the name Byblis agassizi.

The following anatomical characters separate the new species from B. longicornis: It is larger, and has shorter superior antennie (Fig. 9); the lower corner of the cephalon (Fig. $11 c$ ) is not well marked. In alcoholic specimens no ocular pigment is found. The propodal joint of the anterior pereiopoda (fig. 9) is twice as long as the carpal. Each ramus of the last pleopodos (Fig. $11 a$ ) bears long hairs on both edges. On the opposing edges of the rami nofine serration occurs. The telson is twice as longas broad,and bears a pair of minute hairs at its tip (Fig. 11 a).
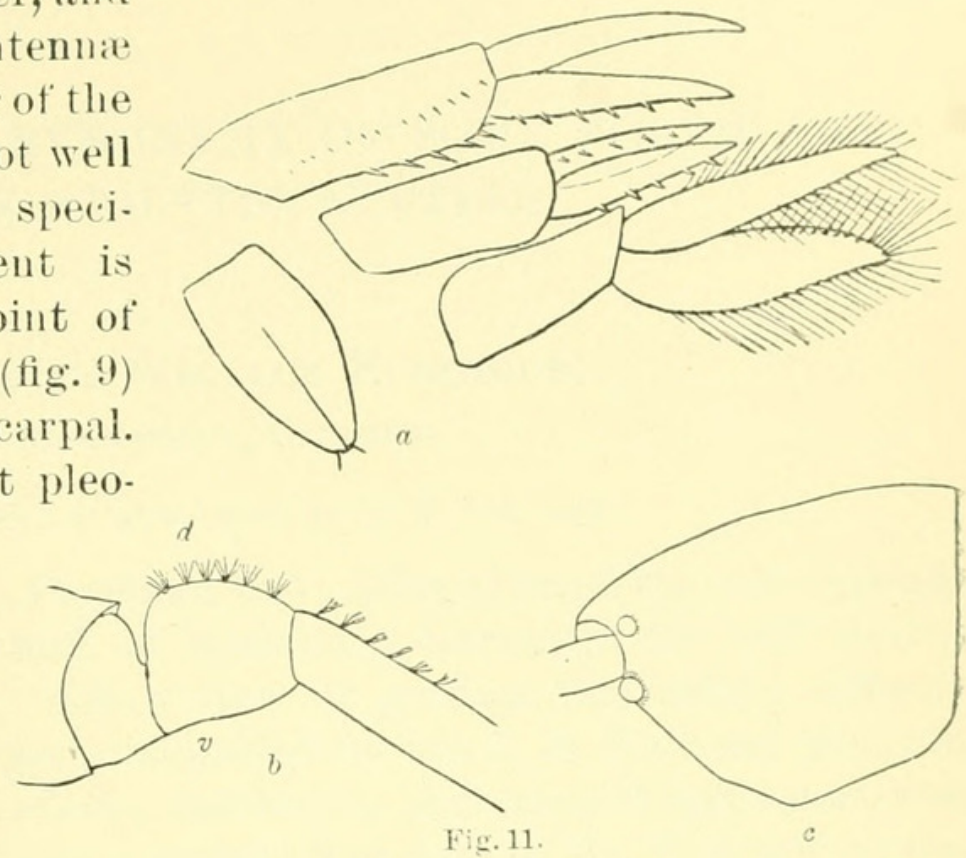

BYBlis AGAssizi, Male.

(a) Three last pleopods and telson, dorsal : spect: $(b)$ inferior antenna, four basal joints of peduncle; $(c)$ cephalon.

\section{BIBLIOGRAPHY}

Bate and Westwood. "Sessile-Eyed Crustacea of Great Britain," 1863-1868, London.

Bate, C. Spence. Catalogue of the specimens of Amphipodous Crustacea in the collection of the British Museum, 1862.

Sars, G. O. Crnstacea of Norway, Christiania and Kjobenhavn, publishing firm of Alb. Cammermeyer, 1893.

Smith, S. I. U. S. Fish Commission Report (1871-72). 


\section{$2 \mathrm{BHL}$ Biodiversity Heritage Library}

Judd, Sylvester D. 1896. "Descriptions of three species of sand fleas (amphipods) collected at Newport, Rhode Island." Proceedings of the United States National Museum 18(1084), 593-603. https://doi.org/10.5479/si.00963801.18-1084.593.

View This Item Online: https://www.biodiversitylibrary.org/item/32799

DOI: https://doi.org/10.5479/si.00963801.18-1084.593

Permalink: https://www.biodiversitylibrary.org/partpdf/5726

\section{Holding Institution}

Smithsonian Libraries

\section{Sponsored by}

Smithsonian

\section{Copyright \& Reuse}

Copyright Status: NOT_IN_COPYRIGHT

This document was created from content at the Biodiversity Heritage Library, the world's largest open access digital library for biodiversity literature and archives. Visit BHL at https://www.biodiversitylibrary.org. 